Esta publicación cientifica en formato digital es continuidad de la revista impresa ISSN-Versión Impresa 0798-1406 / ISSN-Versión on line 2542-3185Depósito legal pp
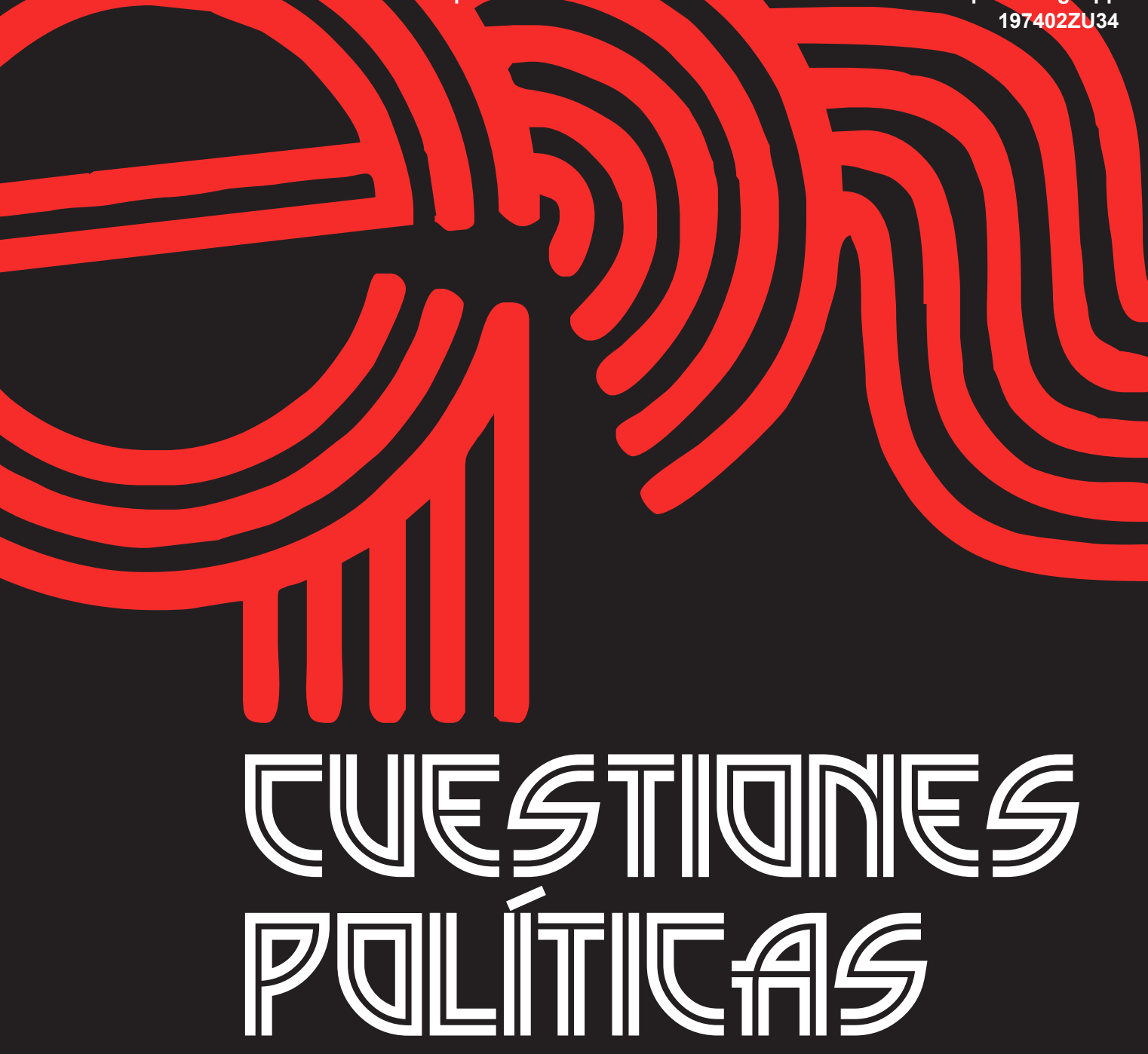

Instituto de Estudios Políticos y Derecho Público "Dr. Humberto J. La Roche" de la Facultad de Ciencias Jurídicas y Políticas de la Universidad del Zulia Maracaibo, Venezuela
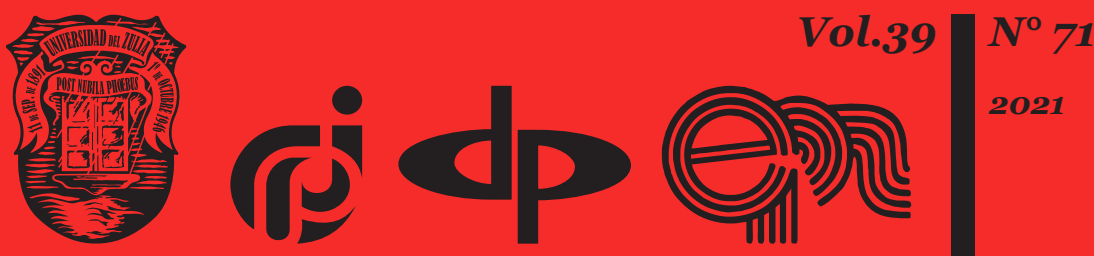


\title{
Racial and Religious Determinants of Terrorism in Western Europe
}

\section{DOI: https://doi.org/10.46398/cuestpol.3971.02}

\author{
Kostyantyn B. Marysyuk * \\ Mykhailo V. Huzela ** \\ Nataliia D. Slotvinska *** \\ Ivo Svoboda **** \\ Igor G. Kudrya *****
}

\begin{abstract}
The gradual rapprochement between peoples, cultures, beliefs involve numerous conflicts with indigenous peoples on ethnic or religious grounds. These conflicts tend to turn into articulation of radical positions and extremist activities. The aim of this study was to analyze the current state of terrorist acts and identify the determinants of terrorism on racial and religious grounds in Western Europe. The statistical method, comparison, graphic analysis, analysis of the Global Index of Terrorism; The European Union reports on the situation and trends of terrorism, as well as the research on terrorism-related issues for 2011-2021, were used as empirical research methods. It is determined that the UK, France, Germany, Greece, Belgium, Spain, Italy, and Sweden are subject to the highest risk of terrorist acts. It was proved that the determinants of terrorism are localized in relation to key issues related to the state of the economic sphere, social development, as well as the spiritual and cultural sphere. Emphasis is placed on the need to overcome the problems associated with terrorist activities by formulating a policy of national means of resolving ethnic and racial issues and active international cooperation. Further research will identify key determinants
\end{abstract} of terrorism in Eastern Europe.

* Doctor of Law, Professor of Department of Criminal Law and Procedure, Institute of Jurisprudence, Psychology and Innovative Education, Lviv Polytechnic National University. ORCID ID: https://orcid. org/oooo-0002-7483-3836

** Candidate of Law, Associate Professor of Department of Criminal Law and Procedure, Institute of Jurisprudence, Psychology and Innovative Education, Lviv Polytechnic National University. ORCID ID: https://orcid.org/oooo-0002-2254-6990

*** Candidate of Law, Assistant of Department of criminal law and procedure, Institute of Jurisprudence, Psychology and Innovative Education, Lviv Polytechnic National University. ORCID ID: https://orcid. org/oooo-0oo2-2756-4557

**** Guarantor of security management studies, Associate Professor of AMBIS, a.s. Vyská škola. ORCID ID: https://orcid.org/o0oo-0002-0941-4686

***** Doctor of Philosophy, Associate Professor of Department of Philosophy and History, Humanitarian Institute, V.I. Vernadsky Taurida National University. ORCID ID: https://orcid.org/o0oo-00024324-1336 
Keywords: terrorism and state; democracy and extremism; national security; determinants; conflicts.

\section{Determinantes raciales y religiosos del terrorismo en Europa occidental}

\section{Resumen}

El acercamiento gradual entre pueblos, culturas, creencias implica numerosos conflictos con los pueblos indígenas por motivos étnicos o religiosos. Estos conflictos tienden a convertirse en articulaciones de posiciones radicales y actividades extremistas. El objetivo de este estudio fue analizar el estado actual de los actos terroristas e identificar los determinantes del terrorismo por motivos raciales y religiosos en Europa Occidental. Se empleo el método estadístico, comparativo, análisis gráficos, análisis del Índice Global de Terrorismo; Los informes de la Unión Europea sobre la situación y las tendencias del terrorismo, así como la investigación sobre cuestiones relacionadas con el terrorismo para 2011-2021, de modo que se utilizaron como métodos de investigación empíricos. Se determina que el Reino Unido, Francia, Alemania, Grecia, Bélgica, España, Italia y Suecia están sujetos al mayor riesgo de actos terroristas. Se comprobó que los determinantes del terrorismo se localizan en relación con cuestiones clave relacionadas con el estado de la esfera económica, el desarrollo social, así como la esfera espiritual y cultural. Se hace hincapié en la necesidad de superar los problemas asociados con las actividades terroristas mediante la formulación de una política de medios nacionales para resolver los problemas étnicos y raciales y la cooperación internacional activa.

Palabras clave: terrorismo y estado; democracia y extremismo; seguridad nacional; determinantes; conflictos.

\section{Introduction}

Acceleration of the manifestation of factors that demonstrate the diversity of the world, its differentiation, the authenticity of cultural, linguistic, ideological manifestations of local societies is significant. Ideologically constructed manifestations of one's identity give rise to growth in the world of conflicts, misunderstandings, and xenophobia. This often turns into extremist (terrorist) actions by certain members of certain groups of like-minded people and entails tragic consequences. The countries of Western Europe, which experience complex consequences of 
multiculturalism, given the increase in the flow of immigrants and refugees in recent decades, have not avoided terrorist acts. So, it should be noted that a significant number of terrorist incidents occur on ethnic and racial grounds. Terrorist activities in this study are considered to be the threat or actual use of violence by individuals or groups of individuals to achieve political, economic, religious or social goals.

According to the Global Terrorism Index (GTI), about 100,000 people died in terrorist attacks between 2014 and 2017 (Institute for Economics and Peace, 2018; 2019; 2020). In 2019, there were almost 8,500 terrorist attacks worldwide, carrying away more than 20,300 people, including 5,460 criminals and 14,840 of their victims. It should be noted that the number of terrorist attacks in Western Europe decreased by 6\% from 2018 to 2019 (from 203 to 191 incidents, respectively), continuing the downward trend from 2015. Mass terrorist attacks in 2019 in Western Europe remained relatively infrequent. Of the 191 terrorist attacks, nine were incidents in which four people were injured or killed (University of Maryland, 2019). According to the German intelligence service (Verfassungsschutz), there were about 4,000 politically or religiously motivated crimes in the country in 2017 (BMI, 2018). A representative survey in France found that 16\% of the adult population and $27 \%$ of young people aged 18 to 24 agree with the ISIS goals (Fischer, 2014).

European nations have faced security challenges in recent decades, the violence and consequences of terrorism have become tragic for many people and communities. The resurgence of ethno-nationalist populist movements across Europe has further strengthened the perception of ethnic and religious minority groups as dangerous (Amnesty International and the Open Society Foundations, 2021). Despite the decline in the total number of attacks and deaths caused, religiously motivated terrorist attacks are on the rise (Løvlien, 2021).

Analysis of data on terrorist acts shows that nationalist ideology is a more common feature than religious ideology in modern terrorism. Religious terrorist groups cause more deaths than other types of terrorist acts. Groups classified as exclusively Islamist have caused more deaths than all other nationalist groups. Modern religious terrorism threatens more people (Romano and Phelps, 2019). Some scholars identify Islamic ideology as the direct cause of the radicalization of Muslims, leading to extremist actions and terrorist attacks. Another view is that Islamist groups formulate the demands and agenda of radicalized people (Egger and MagniBerton, 2021). In Western Europe, immigration has some connection to the level of terrorism in the country, which determines dissatisfaction with the existence of migrants and changes in social order but is not related to economic competition between the local population and immigrants (McAlexander, 2020). 
Radicalization and extremism can be described as the result of a number of (social, individual) determinants (Lerner, 2018) that influence the development of extremist behaviour. Researchers (Kis-Katos et al., 2014) argue that terrorist acts have different determinants, based on the problems of individual radical groups, different opportunities to reach compromises, and their own organizational constraints. The ideological foundations of a terrorist group can be motivated by various determinants based on their own ideology. For example, ethnic discrimination may be relevant to the manifestation of nationalist-separatist terrorism (Brockhoff et al., 2016). But the determinants of ethnic and religious terrorism have both differences and common features (Kis-Katos et al., 2014).

The problem of growing inequality due to austerity policies has led to a decline in social mobility, which has affected both the local population and national minorities, in particular in urban post-industrial settlements. This has exacerbated identity, citizenship and affiliation (especially in parts of Western Europe where industrial cities have faced a decline). Some changes in the local economy have led to a crisis, where the traditional practice of patriarchy has been threatened by the liberalization of labour markets, complicated by issues of identity uncertainty (perceptions of citizenship, belonging to religious and ethnic groups). The impact of these structural and cultural changes has led to the desire of far-right groups to avoid the risks of policy expansion based on diversity and multiculturalism (Abbas, 2020).

Given the conquest of right-wing populism and ethnic nationalism in Western European society, the problem of a general right-wing movement with the speeches of political leaders who support a broader transnational discourse is growing (Froio and Ganesh, 2018). This applies not only to developed Western democracies such as the United Kingdom, Germany and the Netherlands, but also to other liberal states such as Poland, Hungary and Slovakia (Halikiopoulou, 2017). There is a need to assess the dynamics of radicalization as embedded in social processes at the structural level, where concerns about identity, belonging and self-realization are fundamental (Abbas, 2020).

Ethnic identity refers to the feeling of affiliation with an ethnic group and the part of thinking, perception, feelings and behaviour that is due to belonging to an ethnic group. Religious identity is a specific type of identity. This is the feeling of group religious membership and the importance of such participation in the group, as it relates to personal philosophy (Ngari and Reva, 2017). If religion is understood as an ideology, many world ideologies tend to show a high level of intolerance, which leads to violence (Tarlow, 2017).

Actions that are deeply biased in terms of ethnic affiliation, religion, and similar factors arise a sense of discrimination in communities, creating 
an impression of intentional state pressure on communities through the religion or ethnic affiliation of members. This discrepancy in the relationship between states and ethnic or religious groups raises serious concerns about discrimination and equal treatment of the law (Ngari and Reva, 2017).

At the broadest level, political, religious and other extremism is defined as a significant deviation in attitude and behaviour from basic legal and political norms and values within the social system (society or state), which seek to abolish and replace them (Beelmann et al., 2017). For example, terrorist activities based on religious and ethnic factors may arise from incomplete modernization in the social, political, and cultural spheres due to the clash of the modern and the traditional (Pain, 2007). The rise of right-wing nationalism can be seen as a response to growing European integration, which expresses transitional and modernization difficulties (Straume, 2012).

The model of radicalization begins with the definition of terrorist acts in several ways: a significant deviation in attitude and actions from specific fundamental, political, legal and humanitarian norms and values. The main issue is the values and goals that underlie views and actions, not the violence used to achieve them. But judgments about radicalization and extremism do not necessarily have to be based on clearly defined attitudes and actions. Interconnected but different processes of social development are central to radicalization and extremism: problems of identity, prejudice, political or religious ideologies, and antisocial attitudes and behaviours. These processes are caused by real social or individual conflicts and are marked by constant intergroup processes (Beelmann, 2020).

Racism can be characterized by the promotion of natural and hereditary differences between races, with the main belief emphasizing the superiority of one race over another, which is reduced to a certain incompatibility of habits and cultures. Non-natives are perceived as a threat to host communities, based on xenophobia, which is defined as fear, hatred or hostility towards "foreigners" (Mudde, 1995).

The debate on security in Europe borders on ideology-driven discussions on migration, social change and terrorism. Relative security in Europe may explain the rise of xenophobic politics by Western political actors, who believe that globalization is causing irreversible changes in the very nature of European society (Richards, 2017). Extreme political parties often propose to redistribute resources outside certain subgroups of society, such as ethnic minorities or citizens living in certain regions (Brückner and Grüner, 2020).

Conceptually, extremism gets its essence through association with other ideas - totalitarianism and terrorism, referring to the opposition of such concepts as democracy, openness, liberalism, tolerance and moderation 
(El-Ojeili and Taylor, 2020). Based on the features most often mentioned in the existing definitions of extremism, it can be noted that authoritarianism, anti-democracy and nationalism determine the properties of extremism. In contrast, xenophobia and racism are concomitant characteristics of the concept. Right-wing extremism is an ideology that embraces antidemocracy and nationalism (Carter, 2018).

Given the undeniable importance of the problem, the aim of this study is to identify the racial and religious determinants of terrorism in Western Europe. The main objectives of the study are: obtain information on terrorist acts on racial and religious grounds based on a sample and analysis of the Global Database on Terrorism on the number of terrorist acts in Western Europe; determine the level of terrorist threat based on the analysis of data from the Global Terrorism Index to identify the risk of terrorist acts in Western Europe; identify the key determinants of the emergence of terrorist acts in Western Europe on the basis of modern research; propose approaches that can deter the development of terrorism on racial and religious grounds.

\section{Methods}

Information and analytical sources, which contain processed data on terrorist activities, as well as studies that are indexed in the Scopus scientometric database were used as an empirical basis. The materials for the study were the Global Database on Terrorism (University of Maryland, 2021); the Global Terrorism Index (GTI) study (Institute for Economics and Peace, 2020); European Union reports on the situation and trends of terrorism (Europol, 2021), and scientific articles examining terrorismrelated issues for 2011-2021.

The use of the Global Terrorism Database (GTD) is related to the fact that it includes information on domestic and international terrorist acts around the world from 1970 to 2019, and includes more than 200,000 cases. The National Consortium for the Study of Terrorism and Responses to Terrorism (START) provides access the GTD database online for better understanding, detailed research information and prevention of terrorist acts (University of Maryland, 2021). The use of the Global Terrorism Index (GTI) (Institute for Economics \& Peace, 2020) helped to determine the level of terrorist activity in Western Europe and to determine which countries and to what extent face a terrorist threat. The European Union's Terrorism Situation and Trends Report (Europol, 2021) provided information on terrorist attacks and terrorism-related arrests in the European Union (EU) in 2020, submitted to Europol by EU Member States. Search and analysis of scientific articles allowed us to identify the main determinants of terrorism in Western Europe. 
According to the categories of variables (University of Maryland, 2018) contained in the Global Terrorism Database (GTD), the selection of the necessary information on terrorism on racial and religious grounds involves the following steps. The first limitation was the separation of Western European countries according to a sample based on the regional classifier - Western Europe. The next step was to select from the total number of terrorist incidents those that concerned only racial and religious incidents. According to the classifier (University of Maryland, 2018), incidents related to racial and religious factors are identified by the codes: 69 - Religion Identified, 71-Race/Ethnicity Identified, 85-Religious Figure, 86-Place of Worship, 87 - Affiliated Institution. The last approach is separation of the information on terrorist acts on racial and religious grounds for 20002019. A comparative analysis was conducted based on the obtained data.

A study of the Global Terrorism Index for 2017-2020 and the use of a graphical method of analysis allowed identifying Western European countries with the highest risk of terrorist acts and changes in their level. At the final stage, the methodology included the identification of the main determinants of terrorism in Western Europe on the basis of research on terrorism issues for 2011-2021. The result of generalization was to determine the directions of localization of issues that give rise to the determinants of racial and religious terrorism.

The research procedure included the following stages: determining the countries in which the terrorist acts on racial and religious grounds were reported; analysis of the level of terrorist threat; identification of key determinants of terrorism on racial and religious grounds in Western Europe.

\section{Results}

The number of terrorist acts on racial and religious grounds in Western Europe in 2000-2019 was determined based on the results of sampling information from the Global Terrorism Database, which is presented in Table 1.

Restrictions of Western European countries on the basis of the reginal classifier - Western Europe - identified 18 countries of Western Europe, which recorded terrorist acts on racial and religious grounds in 2000-2019 (Table 1). 
Table 1. Number of terrorist acts on racial and religious grounds in Western Europe in 2000-2019.

\begin{tabular}{|c|c|c|c|c|c|c|}
\hline \multirow[b]{2}{*}{ Country } & \multirow[b]{2}{*}{$\begin{array}{l}\text { Number } \\
\text { of } \\
\text { terrorist } \\
\text { acts }\end{array}$} & \multicolumn{5}{|c|}{ Target/Victim Subtype } \\
\hline & & $\begin{array}{l}69- \\
\text { Religion } \\
\text { Identified }\end{array}$ & $\begin{array}{c}71- \\
\text { Race/ } \\
\text { Ethnicity } \\
\text { Identified }\end{array}$ & $\begin{array}{l}85- \\
\text { Religious } \\
\text { Figure }\end{array}$ & $\begin{array}{c}86- \\
\text { Place of } \\
\text { Worship }\end{array}$ & $\begin{array}{c}87- \\
\text { Affiliated } \\
\text { Institution }\end{array}$ \\
\hline Austria & 3 & 1 & 1 & & 1 & \\
\hline Belgium & 6 & 1 & & 1 & 4 & \\
\hline Cyprus & 2 & & & & 2 & \\
\hline Denmark & 2 & & & & 2 & \\
\hline Finland & 3 & & & & 3 & \\
\hline France & 48 & 6 & 3 & 5 & 34 & \\
\hline Germany & 32 & 1 & 6 & & 24 & 1 \\
\hline Greece & 11 & 3 & 2 & & 6 & \\
\hline Iceland & 1 & & & & 1 & \\
\hline Ireland & 1 & & & & 1 & \\
\hline Italy & 17 & & 3 & & 13 & 1 \\
\hline Malta & 1 & & & & 1 & \\
\hline Netherlands & 8 & & & & 8 & \\
\hline Norway & 3 & & 1 & & 2 & \\
\hline Spain & 9 & & 2 & 1 & 6 & \\
\hline Sweden & 12 & 1 & & & 10 & 1 \\
\hline Switzerland & 1 & 1 & & & & \\
\hline $\begin{array}{c}\text { United } \\
\text { Kingdom }\end{array}$ & 146 & 49 & 15 & 2 & 72 & 8 \\
\hline
\end{tabular}

Source: compiled based on (University of Maryland, 2021)

Accordingly, the comparison of terrorist acts on racial and religious grounds (8.48\%) with the total number of terrorist acts for other reasons (91.52\%) in Western Europe in 2000-2019 is presented in Figure 1. 


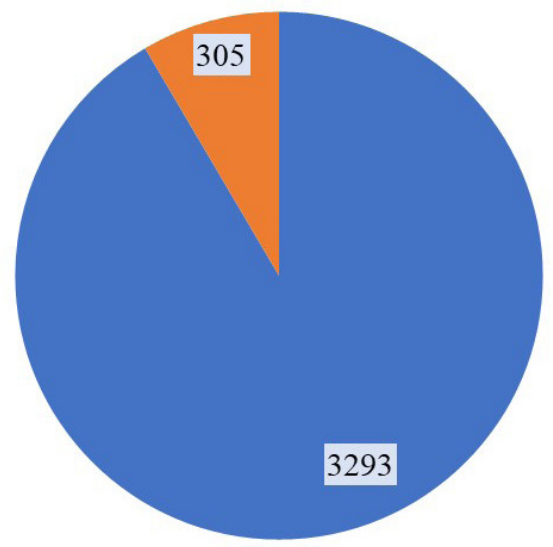

- Other reasons

Ethnic and religious grounds

\section{Figure 1. The number of terrorist acts on racial and religious grounds in the total number of terrorist acts in Western Europe in 2000-2019}

A study of the Global Terrorism Index in EU member states for 20172020 showed that the highest risk of terrorist acts was found in the UK, France, Germany, Greece, Belgium, Spain, Italy and Sweden (Figure 2). This information confirms the preliminary data on the number of terrorist acts on racial and religious grounds in Western Europe in 2000-2019 (Table 1). It should be noted based on the data obtained, that the situation in the studied countries of Western Europe regarding terrorist acts on racial and religious grounds correlates with the results that reflect the situation regarding the general trends of the risk of terrorist threats.

It can be noted from the data obtained during the study, that the issue of terrorist acts has become more acute in the EU countries due to the influence of ISIS. ISIS terrorists attacked individual targets and public places, attracting recruiters from European countries. Most of the incidents in Western Europe were based on the use of various means to injure or kill people. For example, the deadly attempted attack on a synagogue in Germany in October 2019 demonstrated the serious danger of terrorism on racial and religious grounds. The majority of terrorism-related arrests in France have been made against individuals and groups suspected of involvement in ISIS. The German government has identified Islamist terrorists and terrorism on racial or religious grounds as the greatest threat to national security. The United Kingdom continues to stabilize the situation in Iraq and northeastern Syria, which has the potential to combat counter-terrorism and ISIS activities, and remains a top priority. 
According to the latest data from the European Police Office (Europol), religious terrorism in the EU Member States remains the greatest terrorist threat. There were three terrorist attacks in the UK in 2020, and Switzerland was attacked by two jihadists. So, there were 15 completed jihadist attacks in Europe (EU, Switzerland and the UK) in 2020, which was twice as many as in 2019 in the EU (including the UK). In 2020, France and Spain reported 14 terrorist attacks by ethno-nationalists and separatists targeting infrastructure (Europol, 2021).

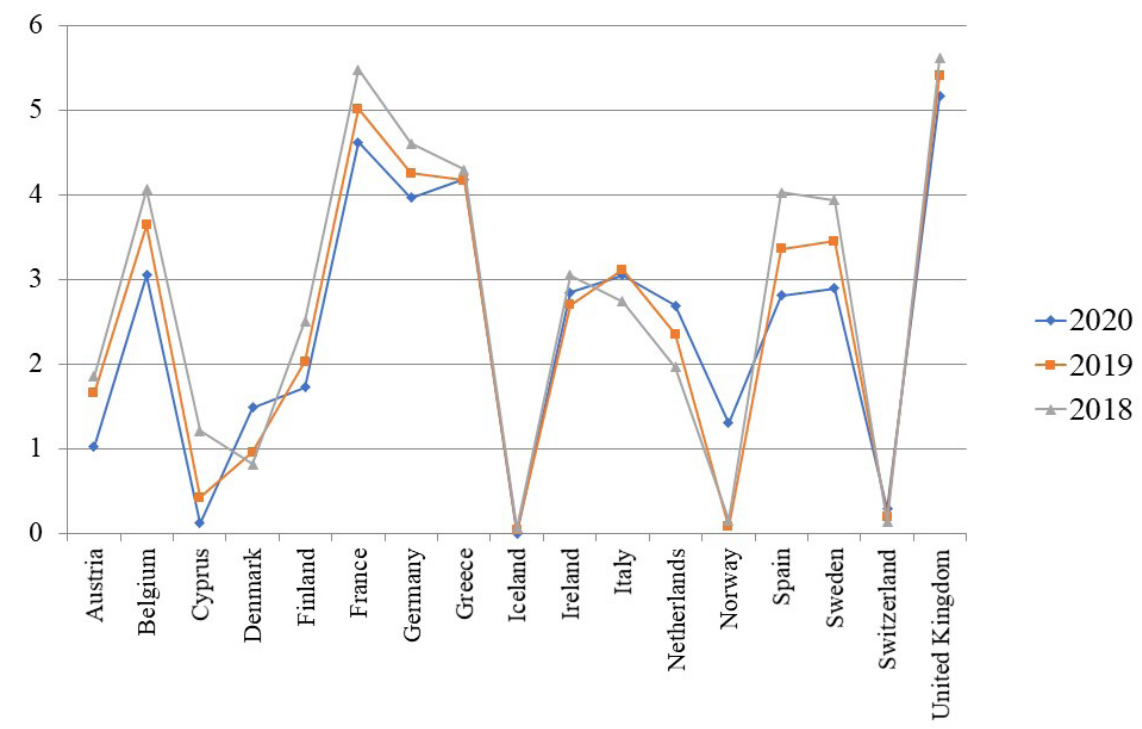

Figure 2. Global Terrorism Index in EU Member States for 2017-2020 (Institute for Economics and Peace, 2020; Institute for Economics and Peace, 2019; Institute for Economics and Peace, 2018)

The next result, which was obtained according to the methodological approach, is the identification of the main determinants of terrorism in Western Europe. The main determinants of terrorism are identified based on the study of terrorism-related issues for 2011-2021 (Table 2). 
Table 2. Key determinants of terrorism

\begin{tabular}{|l|l|}
\hline \multicolumn{1}{|c|}{ Determinants of terrorism } & \multicolumn{1}{|c|}{ Source } \\
\hline $\begin{array}{l}\text { Uneven economic development, } \\
\text { difficult economic conditions, declining } \\
\text { economic growth }\end{array}$ & $\begin{array}{l}\text { (Shahbaz, 2013; Meierrieks, 2014; } \\
\text { Poveda, 2012; Hou, 2021) }\end{array}$ \\
\hline Income inequality & $\begin{array}{l}\text { (Shahbaz, 2013; Sanso-Navarro et al., } \\
\text { 2021) }\end{array}$ \\
\hline $\begin{array}{l}\text { Lack of education, education coverage } \\
\text { level }\end{array}$ & $\begin{array}{l}\text { (Shahbaz, 2013; Nurunnabi and } \\
\text { Sghaier, 2018) }\end{array}$ \\
\hline $\begin{array}{l}\text { Unemployment, employment rate, } \\
\text { labour market conditions }\end{array}$ & $\begin{array}{l}\text { (Shahbaz, 2013; Okafor and Piesse, } \\
\text { 2018; Ismail and Amjad, 2014; Okafor } \\
\text { and Piesse, 2018; Nurunnabi and } \\
\text { Sghaier, 2018; Sanso-Navarro and } \\
\text { Vera-Cabello, 2020; Sanso-Navarro et } \\
\text { al., 2021) }\end{array}$ \\
\hline $\begin{array}{l}\text { Significant number of people with low } \\
\text { living standards (low GDP per capita) }\end{array}$ & $\begin{array}{l}\text { (Shahbaz, 2013; Ismail and Amjad, } \\
\text { 2014; Poveda, 2012; Tahir et al., 2019; } \\
\text { Tahir, 2020) }\end{array}$ \\
\hline Increasing population density & (Freytag et al., 2011; Hou, 2021) \\
\hline $\begin{array}{l}\text { Lack of effective and strong political } \\
\text { control, political instability, civil wars, } \\
\text { number of refugees }\end{array}$ & $\begin{array}{l}\text { (Okafor and Piesse, 2018; Tahir et } \\
\text { al,.2019; Coggins, 2015; Nurunnabi } \\
\text { and Sghaier, 2018; Tahir, 2020; Hou, } \\
\text { 2021) }\end{array}$ \\
\hline Ethnic, linguistic diversity of society & (Gassebner and Luechinger, 2011) \\
\hline $\begin{array}{l}\text { Religious diversity of society, religious } \\
\text { fanaticism }\end{array}$ & $\begin{array}{l}\text { (Gassebner and Luechinger, 2011; } \\
\text { Halkos } \text { et al., 2017) }\end{array}$ \\
\hline Rising inflation & (Ismail and Amjad, 2014) \\
\hline Accumulation of human capital & (Okafor and Piesse, 2018) \\
\hline The importance of the business sector & (Sanso-Navarro et al., 2021) \\
\hline &
\end{tabular}

According to the identified determinants of terrorism, we can say that they are localized in terms of the key issues of the economic sphere (low level of economic development, poverty, unemployment, inflation, etc.), social development (education, human capital), as well as spiritual and cultural sphere (ethnicity, language, religion). It should be noted based on the aim of our study, that the areas of localization of issues that give rise to the determinants of terrorism on racial and religious grounds, in addition to the directly mentioned problems, are additional problems in the economic and social spheres. This reinforces the causes and consequences of extremist actions on ethnic and religious grounds.

It should be noted that, despite some reduction in terrorist acts in Western Europe, terrorism on racial or ethnic grounds (of jihadist terrorism 
and terrorists coming from conflict zones) is of particular concern. These activities pose significant threats, given the support of an extensive network of EU citizens who are radicalized and may be complicit in terrorist acts on racial and ethnic grounds.

\section{Discussion}

The results of this study have certain features related to the approaches used to identify racial and religious determinants of terrorism. The proposed methodological approaches used in the study were based on information from the Global Terrorism Database. This database contains data on terrorist incidents from 1970 to 2019. The use of data sampling since 2000 has somewhat narrowed the array of information. But given that the period of the last two decades shows a significant increase in the number of terrorist acts and their objective record in the database, we consider this time period sufficient to draw our own conclusions.

The use of the regional classifier - Western Europe - has limited the number to 18 Western European countries (Austria, Belgium, Cyprus, Denmark, Finland, France, Germany, Greece, Iceland, Ireland, Italy, the Netherlands, Norway, Spain, Sweden, Switzerland and the United Kingdom), which reduced the representativeness of the analysis. At the same time, the use of these European countries has been sufficient to demonstrate the share of terrorist acts on ethnic and religious grounds in the total array of terrorist incidents for other reasons. Besides, the restriction of the sample from the Global Terrorism Database only by the codes: $69-$ Religion Identified, 71 - Race / Ethnicity Identified, 85 - Religious Figure, 86 - Place of Worship, 87 - Affiliated Institution shows only a fixed number of consequences of terrorist acts on ethnic and religious grounds. But other target subtypes identified by the Global Terrorism Database may include incidents on ethnic and religious grounds. So, the number of terrorist incidents committed on ethnic and religious grounds may actually be higher. Unfortunately, the Global Terrorism Database does not contain data on the motives for committing terrorist acts.

As we can see from the analysis of research on terrorism on racial and religious grounds, the threats posed to certain religious groups are an important factor in intensifying the radicalization of the belief system, which may have involved nonviolent action. These findings were confirmed by a Dutch study on the impact of collective identity and identity factors on attitudes towards violence in defence of religion or ethnicity (Van Bergen et al., 2015). The results of the study demonstrate the role of religious beliefs and their impact on the willingness to justify terrorism, which is closely linked to the strengthening of religious practices around the world (Egger and Magni-Berton, 2021). 
The findings support evidence that belonging to a lower-middle-income minority group is significantly more likely to support a more radical view of terrorism tactics (Løvlien, 2021). The key determinants of terrorist activity, which are identified in this study, expand the previous results, considering a combination of factors of social development, economic and spiritual and cultural spheres as reasons.

The close link between extremist acts and violence, terrorist acts and the deaths of civilians urges the importance of such topics as security, deterrence, preventive actions, and the protection of democratic heritage; implementation of policies aimed at combating the ideas of xenophobia and intolerance, deradicalization; relevance of diagnosis of economic, social, spiritual and psychological factors.

Modern experience in the fight against terrorism in the world proves that the formation of policies which increase pressure on communities differing in their ideology, culture and religion; identifying them as dangerous and suspicious, distinguishing local communities under national paternalism, can create complications and controversy. Strengthening authoritarian measures can increase the long-term risks of lack of trust between certain communities in the country, complicate the issue of refugee adaptation, which will affect the ability to maintain social achievements based on democratic principles and freedoms.

Countering terrorism involves the development of multi-sectoral policies and measures on the possibilities of intervention, which can be the basis for fighting terrorism. These approaches should use proactive countermeasures, as well as operational security issues, police and intelligence. The fight against terrorism must build the resilience of the community and the ability to protect and counter those problematic features that potentially affect threats to national security. Besides, the effective response of the state to extremist acts and terrorist acts of a religious and ethnic nature should include a number of coordinated actions both within the country and internationally, including security, national minority, religious and immigration policies. The key approaches remain to ensure the development of cultural heritage by states and the provision of opportunities for spiritual and religious activities of national minorities in the territories of indigenous communities of Western Europe.

\section{Conclusion}

The study of the determinants of terrorism on racial and religious grounds in Western Europe is a critical issue, given the possible tragic consequences of extremist activities. The atmosphere of intolerance of ethnic and religious differences is quite common, including the current 
situation in countries with developed democratic values. The available data set analysed in the study allowed us to partially distinguish terrorist acts on ethnic and racial grounds from the total number of terrorist acts in Western Europe in 2000-2019. The analysis demonstrates a high risk of terrorist acts (including ethnic and religious ones) in the United Kingdom, France, Germany, Greece, Belgium, Spain, Italy and Sweden. It is determined that the determinants of terrorism are caused by the problems of the economic sphere, social development, as well as spiritual and cultural sphere. Overcoming the challenges of terrorism must be based on policies that shape both domestic means of resolving ethnic and racial issues and active international action. The obtained results were based on the available data of countries that have come a long way in the development of democratic values and human freedoms. It will be useful to identify the key determinants of terrorism in Eastern Europe in further research.

\section{Bibliographic References}

ABBAS, Tahir. 2020. Far right and Islamist radicalisation in an age of austerity: a review of sociological trends and implications for policy. Available online. In: https://icct.nl/app/uploads/2020/01/TahirAbbasAusterity. pdf. Consultation date: 10/01/2021.

AMNESTY INTERNATIONAL AND THE OPEN SOCIETY FOUNDATIONS. 2021. A Human Rights Guide for Researching Racial and Religious Discrimination in Counterterrorism in Europe. Available online. In: https://www.opensocietyfoundations.org/events/a-humanrights-guide-for-researching-racial-and-religious-discrimination-incounterterrorism-in-europe. Consultation date: 10/01/2021.

BEELMANN, Andreas. 2020. "A social-developmental model of radicalization: A systematic integration of existing theories and empirical research" In: International Journal of Conflict and Violence. Vol. 14, No. 1, pp. 1-14.

BEELMANN, Andreas; JAHNKE, Sara; NEUDECKER, Clara. 2017. "Prävention von Radikalisierungsprozessen: Grundlagen entwicklungsorientierter Maßnahmen” In: Neue Kriminalpolitik. Vol. 29, No. 4, pp. 440-49.

BMI. 2018. Verfassungsschutzbericht 2017. Bundesministerium des Innern. Berlin, Germany.

BROCKHOFF, Sarah; KRIEGER, Tim; MEIERRIEKS, Daniel. 2016. "Heterogeneous terrorism: determinants of left-wing and nationalistseparatist terrorism in Western Europe" In: Peace Economics, Peace Science and Public Policy. Vol. 22, No. 4, pp. 393-401. 
BRÜCKNER, Markus; GRÜNER, Hans Peter. 2020. "Economic growth and political extremism” In: Public Choice. Vol. 185, No. 1, pp. 131-159.

CARTER, Elisabeth. 2018. "Right-wing extremism/radicalism: Reconstructing the concept" In: Journal of Political Ideologies. Vol. 23, No. 2, pp. 157182.

COGGINS, Bridget. 2015. "Does State Failure Cause Terrorism? An Empirical Analysis (1999-2008)” In: Journal of Conflict Resolution. Vol. 59, No. 3, pp. $455-483$.

EGGER, Clara; MAGNI-BERTON, Raùl. 2021. "The role of Islamist ideology in shaping Muslims believers' attitudes toward terrorism: Evidence from Europe” In: Studies in Conflict \& Terrorism. Vol. 44, No. 7, pp. 581-604.

EL-OJEILI, Chamsy; TAYLOR, Dylan. 2020. “The Extremism Industry: A Political Logic of Post-Hegemonic Liberalism" In: Critical Sociology. Vol. 46, No. 7-8, pp. 1141-1155.

EUROPOL. 2021, European Union Terrorism Situation and Trend Report. Publications Office of the European Union. Luxembourg City, Luxembourg.

FISCHER, Max. 2014. One in six French people say they support ISIS. Vox. Available online. In: https://www.vox.com/ 2014/8/26/6067123/isispoll. Consultation date: 10/01/2021.

FREYTAG, Andreas; KRÜGER, Jens; MEIERRIEKS, Daniel; SCHNEIDER, Friedrich. 2011. "The Origins of Terrorism: Cross-Country Estimates of SocioEconomic Determinants of Terrorism” In: European Journal of Political Economy. Vol. 27, pp. S5-S16.

FROIO, Caterina; GANESH, Bharath. 2018. "The transnationalisation of far right discourse on Twitter" In: European Societies. Vol. 21, No. 4, pp. 513-539.

GASSEBNER, Martin; LUECHINGER, Simon. 2011. "Lock, Stock, and Barrel: A Comprehensive Assessment of the Determinants of Terror" In: Public Choice. Vol. 149, pp. 235-261.

HALIKIOPOULOU, Daphne. 2017. A "Right-wing Populist Momentum? A Review of 2017 Elections Across Europe" In: Journal of Common Market Studies. Vol.56, pp. 63-73.

HALKOS, George; MANAGI, Shunsuke; ZISIADOU, Argyro. 2017. "Analyzing the Determinants of Terrorist Attacks and their Market Reactions" In: Economic Analysis and Policy. Vol. 54, pp. 57-73. 
HOU, Dongfang. 2021. "The Formation of Terrorist Groups: An Empirical Analysis" In: Defence and Peace Economics, pp. 1-10.

INSTITUTE FOR ECONOMICS AND PEACE. 2018. Global Terrorism Index 2018: Measuring the Impact of Terrorism. Institute for Economics and Peace. Sydney, Australia.

INSTITUTE FOR ECONOMICS AND PEACE. 2019. Global Terrorism Index 2019: Measuring the Impact of Terrorism, Sydney, November 2019. Available online. In: http://visionofhumanity.org/reports. Consultation date: 10/01/2021.

INSTITUTE FOR ECONOMICS AND PEACE. 2020. Global Terrorism Index 2020: Measuring the Impact of Terrorism, Sydney, November 2020. Available online. In: http://visionofhumanity.org/reports. Consultation date: 04/01/2021.

ISMAIL, Aisha; AMJAD, Shehla. 2014. "Determinants of Terrorism in Pakistan: An Empirical Investigation” In: Economic Modelling. Vol. 37, pp. 320331.

KIS-KATOS, Krisztina; LIEBERT, Helge; SCHULZE, Günther. 2014. "On the Heterogeneity of Terror” In: European Economic Review. Vol. 68, No. 1, pp. 116-136.

LERNER, Richard. M. 2018. Concepts and Theories of Human Development, 4th ed. Routledge. New York, USA.

LØVLIEN, Edvard. 2021. "Radical Beings? How Group Identities Impact Willingness to Justify Terrorism” In: Perspectives on Terrorism. Vol. 15, No. 2, pp. 33-57.

MCALEXANDER, Richard. 2020. "How are immigration and terrorism related? An analysis of right-and left-wing terrorism in Western Europe, 1980-2004” In: Journal of Global Security Studies. Vol. 5, No. 1, pp. 179195.

MEIERRIEKS, Daniel. 2014. "Economic determinants of terrorism. Understanding Terrorism (Contributions to Conflict Management, Peace Economics and Development)" In: Emerald Group Publishing Limited, pp. 25-49.

MUDDE, Camel. 1995. "Right-wing extremism analyzed: a comparative analysis of the ideologies of three alleged right-wing extremist parties (NPD, NDP, CP'86)” In: European Journal of Political Research. Vol. 27, No. 2, pp. 203-224. 
NGARI, Allan; REVA, Denys. 2017. How ethnic and religious discrimination drive violent extremism. Available online. In: https://communitydemocracies.org/app/uploads/2018/o6/aitwr-4-1.pdf. Consultation date: 10/01/2021.

NURUNNABI, Mohammad; SGHAIER, Asma. 2018. "Socioeconomic Determinants of Terrorism" In: Digest of Middle East Studies. Vol. 27, No. 2, pp. 278-302.

OKAFOR, Godwin; PIESSE, Jenifer. 2018. "Empirical investigation into the determinants of terrorism: Evidence from fragile states" In: Defence and Peace Economics. Vol. 29, No. 6, pp. 697-711.

PAIN, Edward. 2007. "Xenophobia and ethnopolotical extremism in postsoviet Russia: dynamics and growth factors" In: Nationalities Papers. Vol.35, No. 5, pp.895-911.

POVEDA, Alexander Cotte. 2012. "Violence and Economic Development in Colombian Cities: A Dynamic Panel Data Analysis" In: Journal of International Development. Vol. 24, No. 7, pp. 809-827.

RICHARDS, Julian. 2017. Extremism, radicalization and security: An identity theory approach. Springer. Berlin, Germany.

ROMANO, Dani; ROWE, Steve; PHELPS, Rob. 2019. "Correlates of terror: Trends in types of terrorist groups and fatalities inflicted" In: Cogent Social Sciences. Vol. 5, No. 1, pp. 1584-1911.

SANSO-NAVARRO, Marcos; SANZ GRACIA, Fernando; VERA-CABELLO, Maria. 2021. "Terrorism Determinants, Model Uncertainty and Space in Colombia" In: Defence and Peace Economics, pp. 1-20.

SANSO-NAVARRO, Marcos; VERA-CABELLO, Maria. 2020. "The socioeconomic determinants of terrorism: A bayesian model averaging approach" In: Defence and Peace Economics. Vol. 31, No. 3, pp. 269-288.

SHAHBAZ, Muhammad. 2013. "Linkages between Inflation, Economic Growth and Terrorism in Pakistan" In: Economic Modelling. Vol. 32, pp. 496506.

STRAUME, Ingerid. S. 2012. "The survival of politics" In: Critical Horizons. Vol.13, No. 1, pp. 113-133.

TAHIR, Muhammad. 2020. "Terrorism and its Determinants: Panel Data Evidence from 94 Countries" In: Applied Research in Quality of Life. Vol.15, No. 1, pp. 1-16. 
TAHIR, Muhammad; IBNE AFZAL, Mustafa; AFRIDI, Miham; NASEEM, Ibrim; BIN SAEED, Barb. 2019. "Terrorism and its determinants in the sub-Saharan Africa region: Some new insights" In: African Development Review. Vol.31, No. 3, pp. 393-406.

TARLOW, Peter. 2017. “The interaction of religion and terrorism” In: IJSSTH, Vol. 16, pp. 1-24.

UNIVERSITY OF MARYLAND. 2018. Global terrorism database codebook. Available online. In: https:/www.start.umd.edu/gtd/downloads/ Codebook.pdf. Consultation date: 03/01/2021.

UNIVERSITY OF MARYLAND. 2019. Global Terrorism Overview: Terrorism in 2019. Available online. In: https://www.start.umd.edu/pubs/START_ GTD_GlobalTerrorismOverview2019_July2020.pdf. Consultation date: 03/01/2021.

UNIVERSITY OF MARYLAND. 2021. Global Terrorism Database. Available online. In: https://www.start.umd.edu/gtd/about/. Consultation date: 10/01/2021.

VAN BERGEN, Diana; FEDDESET, Allard; DOOSJE, Bertjan; PELS, Tomas. 2015. "Collective identity factors and the attitude toward violence in defense of ethnicity or religion among Muslim youth of Turkish and Moroccan Descent” In: International Journal of Intercultural Relations. Vol. 47, pp. 89-100. 

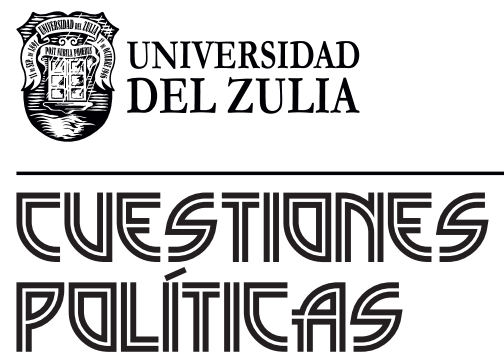

Vol. 39 N $^{\circ} 71$

Esta revista fue editada en formato digital y publicada en diciembre de 2021, por el Fondo Editorial Serbiluz, Universidad del Zulia. Maracaibo-Venezuela 